\title{
Teaching Research of Geology Field Courses: A Case Study from Wuhan University
}

\author{
Tao Wang1,2*, Long Cheng1, Jun Xiao'1, Peng Qi1, Jun Zeng1, Wanrui Hu' ${ }^{1}$, Suifeng Wang ${ }^{3}$ \\ ${ }^{1}$ School of Water Resources and Hydropower Engineering, Wuhan University, Wuhan, China \\ ${ }^{2}$ Department of Energy and Mineral Engineering, Pennsylvania State University, University Park, PA, USA \\ ${ }^{3}$ Faculty of Engineering, China University of Geosciences, Wuhan, China \\ Email: "htwang@whu.edu.cn, jacklcheng@whu.edu.cn,1181217215@qq.com, qipengwhu@163.com, \\ zengjunxt@qq.com, wanrui_hu@whu.edu.cn, wsf960624@vip.qq.com
}

Received 1 May 2016; accepted 17 June 2016; published 20 June 2016

Copyright (C) 2016 by authors and Scientific Research Publishing Inc.

This work is licensed under the Creative Commons Attribution International License (CC BY).

http://creativecommons.org/licenses/by/4.0/

(c) (i) Open Access

\section{Abstract}

The geology field course is the fundamental course in geoscience education. It is an intensive course that applies classroom and laboratory training to solve geological problems in the field. Wuhan University has offered a geology field course for undergraduate students since the 1950s. This paper summarizes and analyzes the teaching research in aspects of field course location, teaching contents and teaching tools since 2010, when the site was changed from the city of Chibi to Zigui County near the Three Gorges reservoir region.

\section{Keywords}

Geology Field Course, Zigui County, Teaching Research

\section{Introduction}

Geology is a highly field-oriented science. A geologist's work is usually outdoors, sometimes in out-of-the way places such as deserts or sparsely populated mountain ranges, and thus the geology field course is an indispensable part of the process (California State University, 2014). The geological knowledge that students learn from textbooks and in the classroom is generally abstract. For a variety of geological phenomena, if the students only learn from the description in a book, their understanding may be one-sided, mechanical, and even wrong. Therefore, in addition to classroom-based geology courses, the students must inspect the field first hand to deepen their understanding of geological concepts and geological process and make the abstract geological theories more concrete. To further enhance the effectiveness of teaching practice, new exploration for field teaching on

\footnotetext{
${ }^{*}$ Corresponding author.
}

How to cite this paper: Wang, T., Cheng, L., Xiao, J., Qi, P., Zeng, J., Hu, W. R., \& Wang, S. F. (2016). Teaching Research of Geology Field Courses: A Case Study from Wuhan University. Creative Education, 7, 1222-1232.

http://dx.doi.org/10.4236/ce.2016.79128 
teaching ideas and teaching methods is essential.

Field camp is a tradition in the education of geologists worldwide. It is an intensive course that applies classroom and laboratory training to solve geological problems in the field. Skills developed in the field course typically include collection of geologic data, constructing measured sections, interpreting geologic structures and geologic mapping (University of Wisconsin-Milwaukee, 2014). Since the 1950s, the geology teaching and research section began the geological sciences classroom and field teaching courses tasks at Wuhan University (Wang et al., 2014). Since then, field education has occupied a central role in the undergraduate geoscience curricula. The principal goal of the field course is to train students to recognize distinct lithological and structural units and their 3-D relationships. Field projects include mapping and interpreting deformed and faulted sedimentary, regional metamorphic, plutonic, volcanic complexes, geological disasters and engineering geology problems. Over the past 5 years, there has still four departments offering traditional geology courses. The total field camp attendance has modest change over the past 6 years (Figure 1).

The development of the geosciences industry may have an impact on geoscience disciplines. Therefore, new requirements are being created for the students of this major. The American Geological Institute (AGI) has investigated the situation in US. The number of geoscience departments offering summer field courses has dropped by 60\% since 1995. In contrast, a 2008 survey of active field courses showed a steady increase in the number of students attending summer field camps (AGI, 2009). The Geological Society of America (GSA) published a volume of special papers on the geoscience field course that is the most influential publication on field geology education in the world. These papers highlight the historical perspectives and continued importance of field education in the geosciences, propose future directions of geoscience field education, and document the value of this education (Whitmeyer, Mogk, \& Pyle, 2009; Paor \& Whitmeyer, 2009; Geissman \& Meyer, 2009; Swanson, \& Bampton, 2009; Wet, Manduca, Wobus, \& Bettisonvarga, 2009; Marshall, Gardner, Protti, \& Nourse, 2009).

However, in China, the Geological Society of China (GSC) has not yet created specialized internships for geological field studies, and therefore, statistics and proceedings are not available. A small number of practitioners have published their teaching experience in some of the domestic teaching publications. The authors, who have taught at Wuhan University for nearly two decades, have developed a summary of the university's undergraduate teaching work, which can be used for students who will have field course later and as a reference for peers within the international scope.

\section{Field Course Site Reselection}

The field course site selection plays an important role in the course because it has a direct influence on the work. The original site for Wuhan University's course was in the city of Chibi, Hubei Province, 150 kilometers from

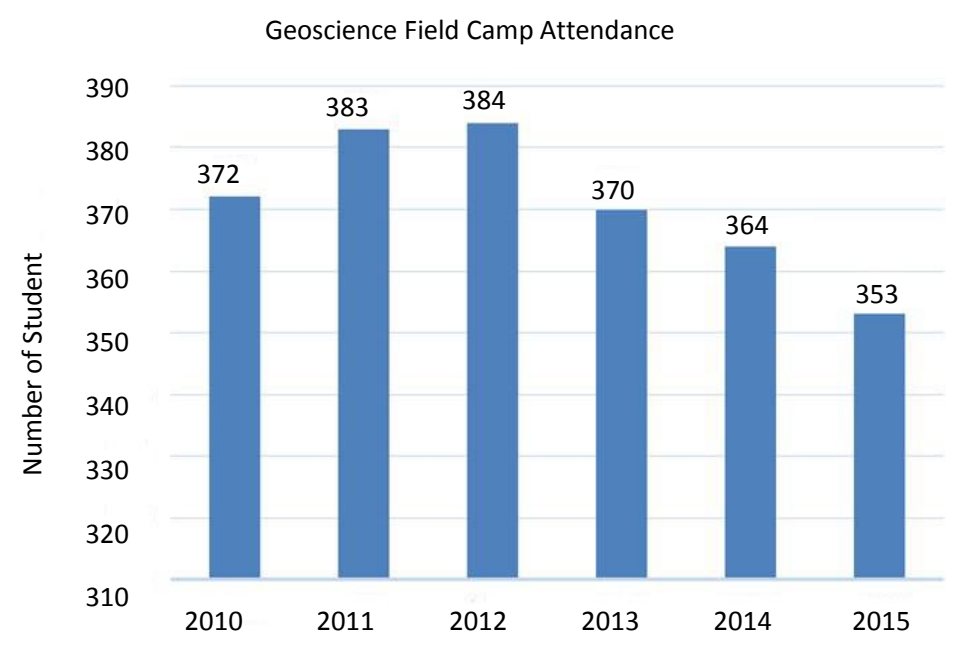

Figure 1. Total field camp attendance during the period from 2010 to 2015. 
Wuhan. A hydroelectric project, namely, the Lushui Dam, was built as the Three Gorges Test Dam. The dam had two purposes: to serve as a site for experiments for the country's large water conservancy and hydropower engineering design and operation, and to permit the comprehensive exploitation and utilization of various water resources. The original field course area was on the south bank of the middle Yangtze River and in the northern slope of Mufu Mountain, where the Proterozoic to Cenozoic strata are well exposed and various lithologies are plentiful. Due to the impact of the crustal movement, the folds and faults developed well. It was once an appropriate engineering geology practice base. However, because of its limitations, including the destruction of the geological outcrops caused by urban construction and the inconvenience of students' learning and living conditions, the field course site was moved to Zigui County, Hubei Province in 2010. The current site is 500 kilometers away from Wuhan and the base where students live is only 1 kilometer away from The Three Gorges Dam (Figure 2). The comparison about the level of two field course sites are shown in Figure 3 in terms of teaching resources, geological conditions, living conditions, etc.

The field course site in Zigui is located in the Huangling anticline of two secondary tectonic units' transition sections, between the Yangtze platform and Hubei-Guizhou platform fold belt and Sichuan platform syncline. In the site, the crystalline basement and cap rock outcrop widely, geological structures are well developed, and rock types are abundant. In addition, the geological teaching content is relatively complete. After an endless geological movement, the site possesses numerous terranes of different periods and different lithologies and various structural traces, which provides a good condition for the researching of the mineral component, texture, and structure of rock and stability influences of rock mass on the engineering. Moreover, the stratum of the Sinian Period in the Three Gorges Project area is one of the best developed important geological sections in China. From bottom to top, the stratum is divided into four stratigraphic units: Liantuo Group, Nantuo Group, Doushantuo Group, and Dengying Group, which together represent the important parts of the Yangtze River Three Gorges National Geological Park (Figure 2(C)).

Because of the down cutting of the Yangtze River and the increasingly frequent human engineering activities, the natural environment is changed gradually in the field course zone. Thus, rock slope stability problems are quite prominent, and geological disaster phenomena, such as natural collapse, landslide and debris flow, are very common. These dangerous phenomena, such as the Lianzi Cliff rock body and the Xintan landslide, are the typical subjects of the engineering geology course contents. Moreover, because of roads and other project construction,

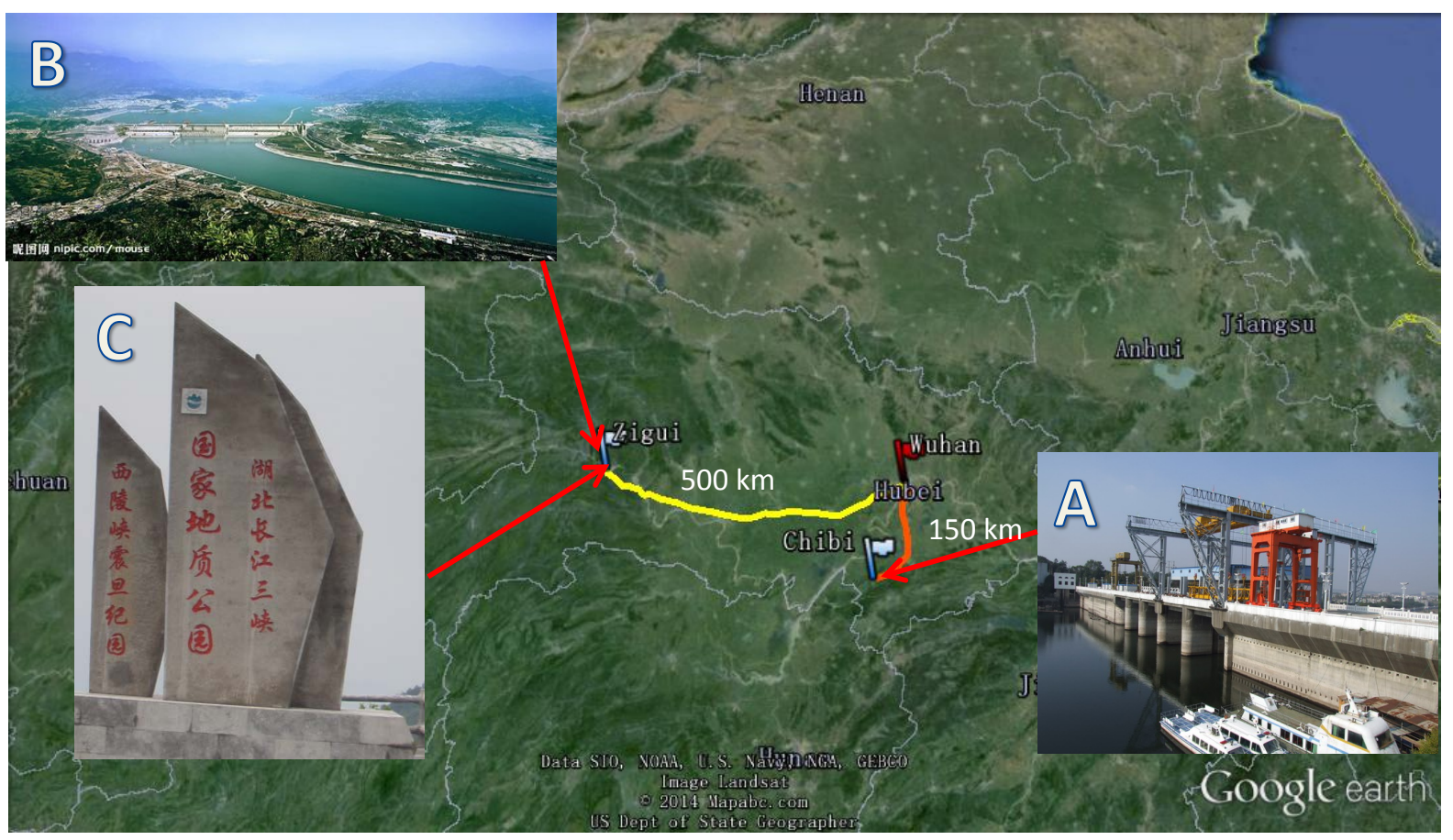

Figure 2. The location of the geology field course changed from the city of Chibi to Zigui County. (A) Lushui water control project; (B) three Gorges Projects in the Yangtze River; (C) the Yangtze River Three Gorges National Geological Park. 


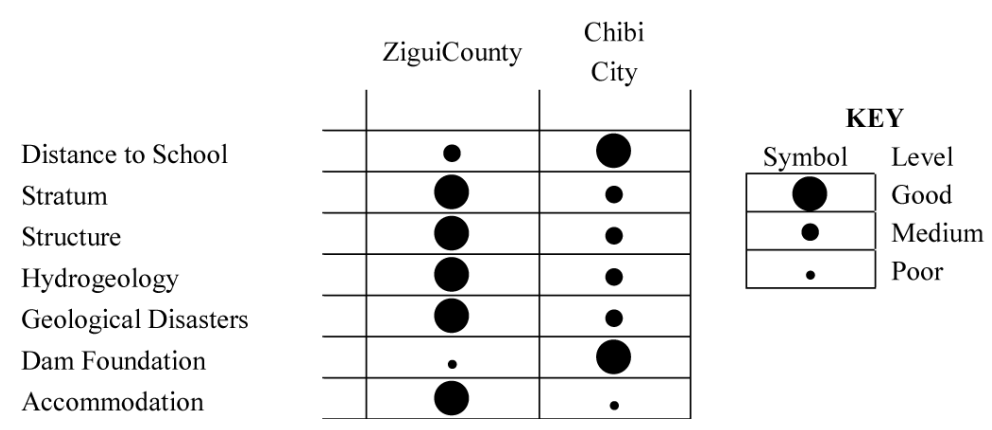

Figure 3. Comparison between Zigui County and Chibi City as field course sites

artificial high slopes have emerged in abundance, generating new and dangerous rock bodies. The slope supporting engineering on the way of practice can be observed everywhere. These typical engineering geological phenomena are taught in the engineering geology classroom and are also important in field teaching.

The well-known Three Gorges Dam, located in the field course site, is a great place for students to visit, study, and make on-the-spot investigations. However, there are a few disadvantages. Three Gorges Dam (Figure 4) was constructed in such a way that the outcrop of rocks and structures are almost completely covered. In addition, the security level of the Three Gorges Dam is high, which limits its use for the practice of teaching to some extent.

In general, the field course site in Zigui, which features rich teaching resources, varied terrain, typical visual phenomena and good living conditions, is an excellent comprehensive practice base with a collection of basic geology and engineering geology. Compared to the field course site in Chibi, the site in Zigui is more appropriate as the field course site.

\section{Field Course Contents}

Geological study resources in Zigui County are plentiful, but field course time is finite. Thus, it is necessary to select the most appropriate geological observation points and geological phenomena for students to study. In choosing practice teaching contents, course leaders take several aspects into consideration: First, courses should combine basic geology and engineering geology. The contents of the teaching course include basic geology, engineering geological phenomena, engineering construction and geological disaster control projects. Additionally, some typical engineering geological phenomena are used as study contents to strengthen students' understanding of engineering geological phenomena. Second, courses combine indoor and outdoor work. Outdoor work is the basis for teaching, while indoor work is the summary and improvement for outdoor work. The two sides are indispensable. Third, the student's personal safety, as well as convenient transportation routes, should be considered. Based on these principles, in order to achieve the purpose of field course of geology, contents of geological field teaching include the following aspects:

\subsection{Teaching Contents in Basic Geology}

Stratum: Along the route (Lanling Brook to Quyuan Town, Sinian strata to Siluric strata), students should understand lithology, stratigraphic contact relation, etc. The outcrop of bedrock strata along the road is good, and the geological boundary is obvious. To understand the geology and geomorphology of the Quaternary, students mainly visit the river valley geomorphology of the Bamboo Sea Park (Figure 4), where they can also find a quarry, waterfalls, steep cliffs, etc.

Structure: Along the route (the Lanling Brook to the Quyuan Town), there are many structural features such as small faults, folds, joints and cleavages. Instructors choose the typical tectonic phenomena as the teaching content (Figure 5). The major fault in Fairy Hill is a large structural phenomenon, and this fault is currently active. Students can research the features of the active fault and analyze the engineering significance of that research. Additionally, because the entire practice area is in the Huangling anticline, the students can summarize the ways to recognize folds of different sizes after finishing this route.

Hydrogeology: The main hydrogeological points in the field site are the Si Brook, the Migong Spring and the 


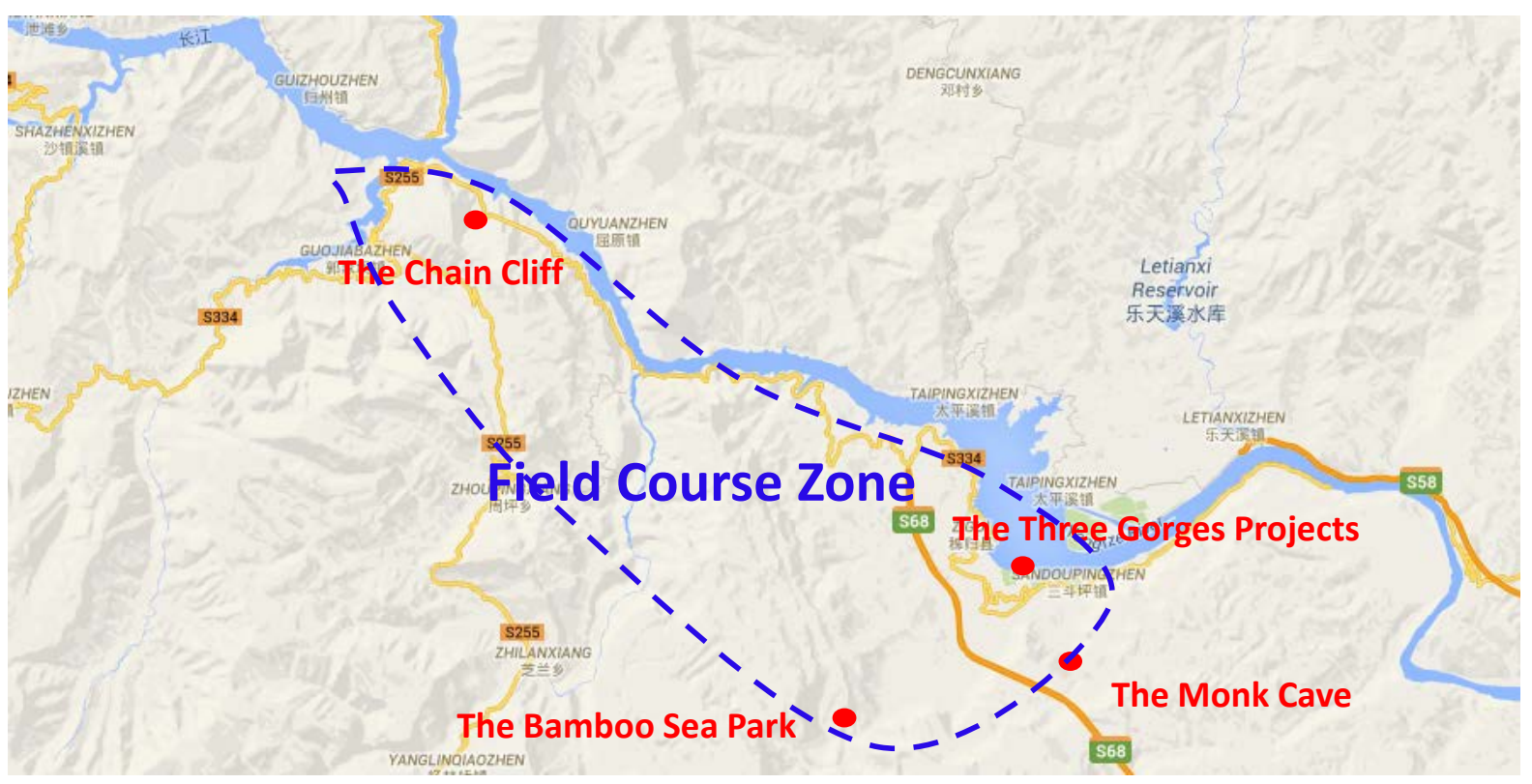

Figure 4. The field course zone map and several landmarks.
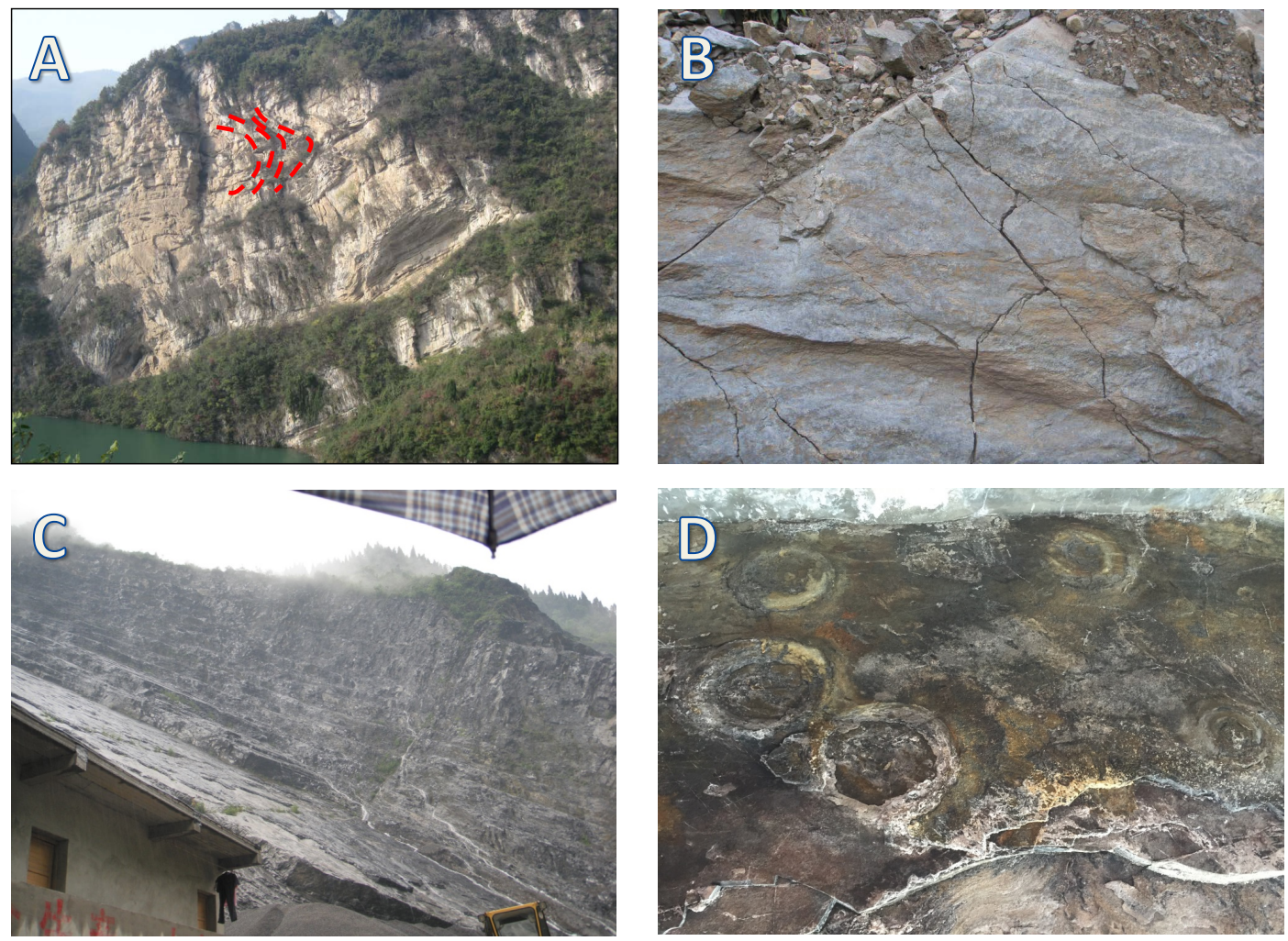

Figure 5. The field study sites related to basic geology. (A) The recumbent fold near the Jiuwan Brook Bridge; (B) fracture distribution in a surface of a granite outcrop; (C) a large layered limestone rock mass of the Dengying Group (Sinian Period) is discovered at a quarry in the Bamboo Sea Park; (D) the bottom of Dengying Formation..

Wudie Water. The Monk Cave (Figure 6) is used to explain the karst phenomenon. Through analysis, the students can learn about the relationship between spring water and the formation of karst, and between karst and engineering construction. 

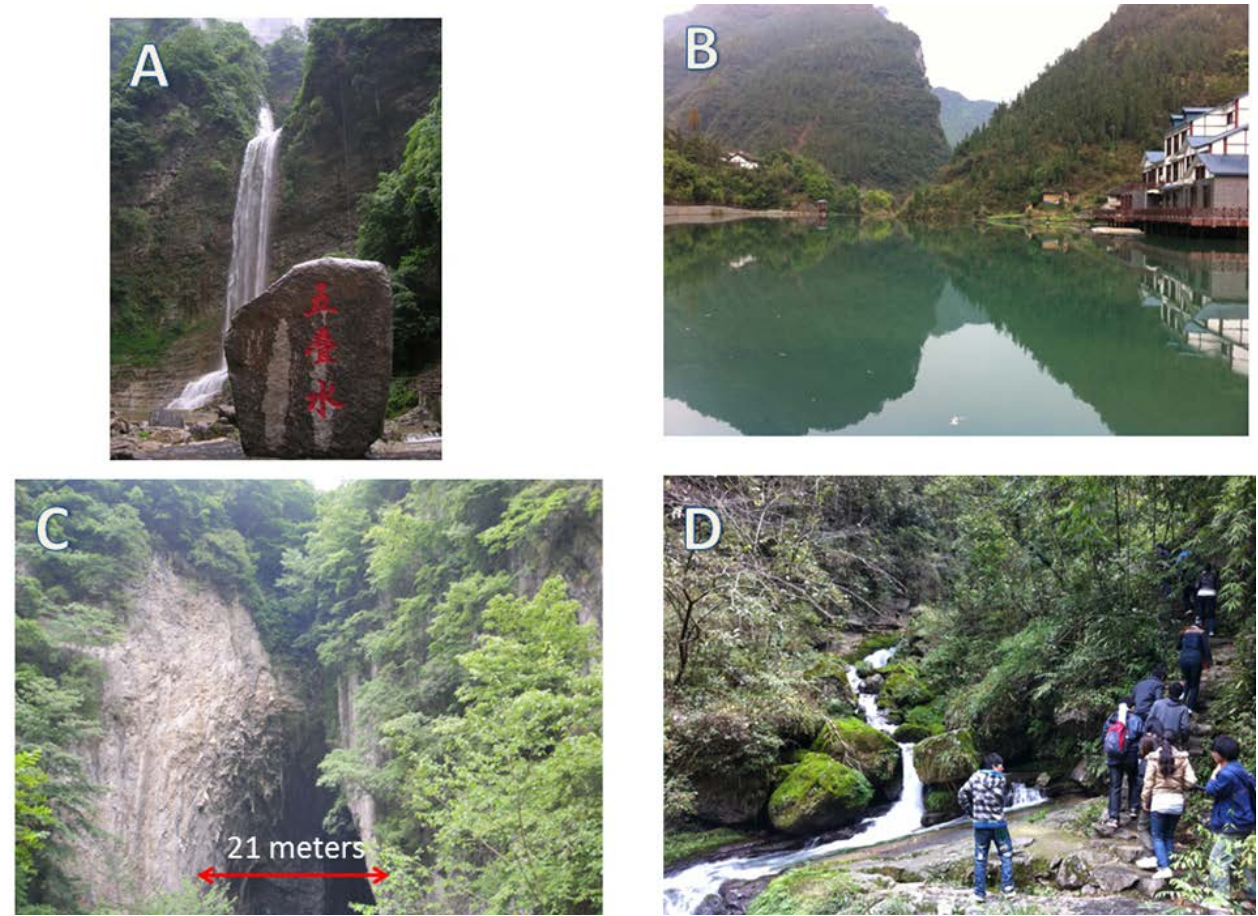

Figure 6. The field study observation points related to hydrogeology. (A) The Wudie Water is afive-staged waterfall located in the Si Brook Park. It is as high as 491 meters and is the highest waterfall in Asia; (B) a small reservoir located in the center of the Bamboo Sea Park called Holy Water Lake; (C) the Monk Cave formed in a soluble limestone rock. The width is 21 meters at the hole of the cave, and height is 40 meters. The depth of the cave is 50 meters; (D) students searching for the source of the Mazing Spring.

\subsection{Engineering Geological Problems and Geological Disasters}

Features of rock weathering crust: Students will observe and learn about granite weathering crust, weathering crust zoning and engineering geological properties of different zones.

Prevention and treatment engineering of unstable rock mass: Students will learn the structural characteristics, causes, human consequences, and engineering controlling measures of the Coffin Rock unstable rock mass. Along the route (the Lanling Brook to the Quyuan Town), students are introduced to the geological structures of the reservoir bank, engineering geological problems of bank slump and prevention and treatment engineering (Figure 7). The Zongyantou dangerous rock body, the Jiuwan Brook dangerous rock body and the Lukouzi sliding mass are good points to be introduced.

The Xintan Slide and Chain Cliff geological disasters: Students will learn some external characteristics, formation mechanism, human consequences, monitoring methods and control measures of the geological disasters.

\subsection{Interior Work (Geological Map and Report)}

After completing the above study tasks, the students choose the appropriate region to draw strata, lithology and engineering geological conditions on a geological profile graph. Drawing a map is part of a comprehensive training, and also quantifies a student's mastery of professional knowledge and ability to work. The aim of writing a report is to cultivate the ability to observe field geological phenomena and to deepen the understanding of geological theory and develop geological thinking.

\section{Use of New Technologies in the Field}

With advances in research in the geosciences, researchers can more clearly understand various geological phenomena. Modern field equipment and new technologies can be applied in the geology field course. The course 

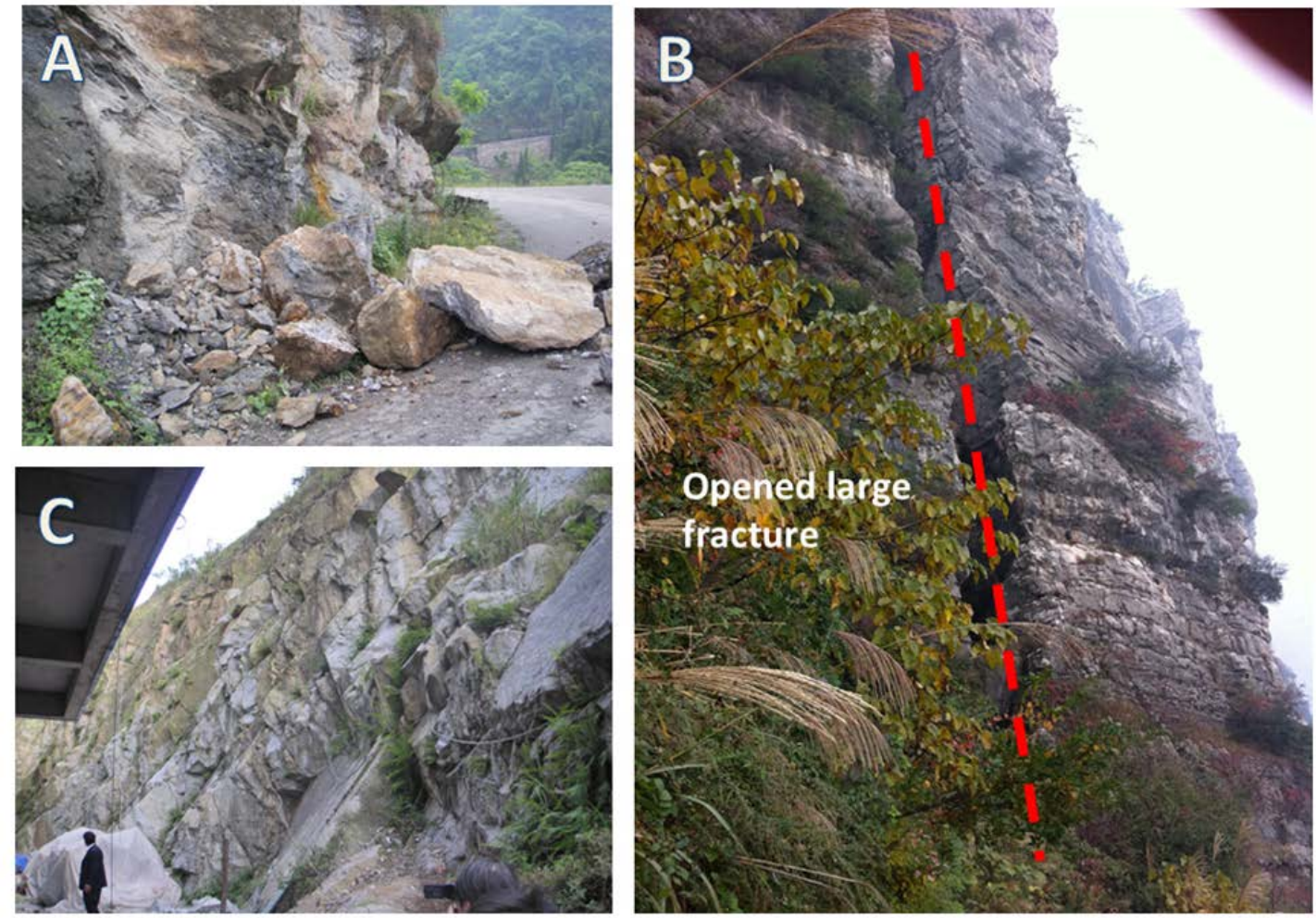

Figure 7. The field study observation points related to geological disasters. (A) Rock avalanche near a road; (B) the Chain Cliff is just on the right bank of the Yangtze River. The total volume of dangerous rock mass is approximately 3.32 million cubic meters, and it has been cut apart by more than ten cracks going deep into coal mine bottom; (C) dangerous rock slope close to a residential area.

utilizes advanced information technology in addition to traditional geological tools such as the compass, magnifying glass, hammer, geological profile survey, and drawing tools to obtain geoscience information. Integrated use of modern technology and means has greatly changed the traditional field teaching methods, bringing the content of geology field course to a new, higher level.

The combined application of GPS and Google Earth: Field course paths and sites labeled by GPS are imported to remote sensing images of the field course area though the corresponding interface. Additionally, this can be performed by importing corresponding longitude and latitude to create the path and the landmark, thus generating a KML (Keyhole Markup Language) file, which is the format Google Earth uses for the exchange of geographic information. If a KML file is copied into a computer, researchers will be able to view the recorded field course route (Figure 8). It is practical to mark every field course site in detail, which contributes to better understanding of specific information about each site. At present, GPS instruments supported by Google Earth include Garmin, Magellan and Wintec WBT-201.

3D geological models: Spatial information management, geological interpretation, spatial analysis and forecasting, geoscience statistics, content analysis and graphical visualization can be combined through 3D geological model technology. A geological body exists in space in three dimensions, and the 3D geological model is used to display 3D shapes, grade distribution and fault characteristics of rock mass, and so on.

These models can help students understand the spatial distribution of rock mass and gain a better understand the geological content of the field course. The geological targets of modeling vary greatly, and the models attempt to show not only the geography but also the properties of a site. However, no matter how complex the geological body is, it can be generally described by four types of data: point, line, face and body. A 3D modeling tool, GoCAD (Geological Object CAD), especially designed for geological modeling, has demonstrated relatively good performance for 3D model construction and spatial analysis (Losier, Pouliot, \& Fortin, 2007). GoCAD allows the user to develop different classes of objects (e.g., point sets, lines, surfaces, voxets, S-grids). Data are commonly imported as point sets, well-based information (e.g., geology, logs of properties), or grid- 


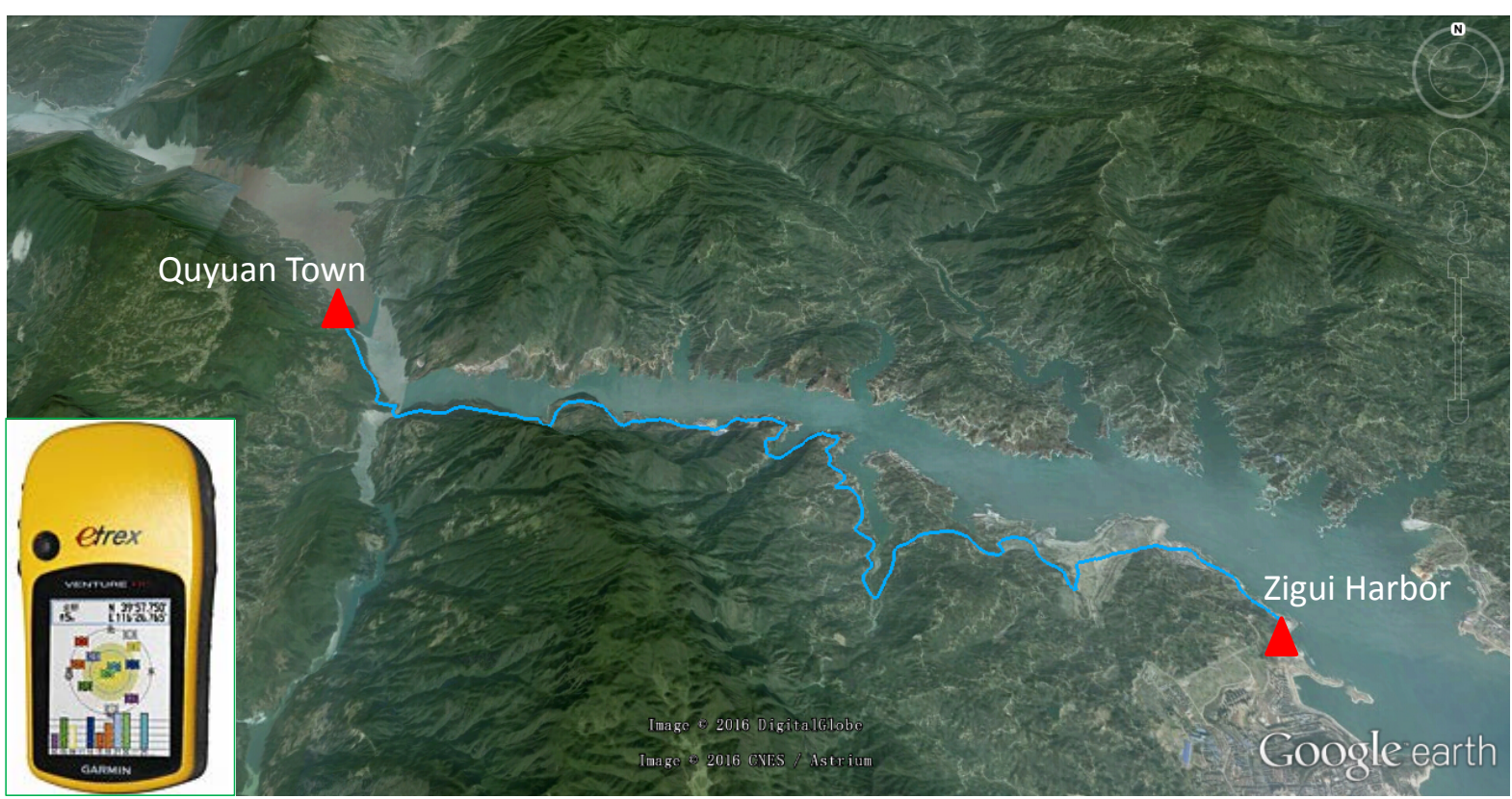

Figure 8. The distribution of geology field course sites along the route from the Lanling Brook to the Quyuan Town. The left bottom is a handheld GPS manufactured by Garmin.

based 2D or 3D information (geological cross-sections, geochemical, and geophysical data) (Feltrin, Mclellan, \& Oliver, 2009). The core of the GoCAD application is the Discrete Smooth Interpolation method or DSI (Mallet, 1989; Mallet, 2002). The interpolation of a complex geological dataset is solved with this algorithm by reducing a global problem (e.g., fitting a triangulated surface to a cluster of fuzzy control points) to a discrete number of smaller linear problems. Subsequently, a finite-difference approximation is used to find a spline function that locally fits the geological dataset. DSI is then utilized to obtain smooth, interpolated objects while following predefined linear constraints imposed by the integrated geological information (Feltrin, Mclellan, \& Oliver, 2009). Using this algorithm, 3D surfaces, volumes and grids can be obtained by interpolating simple features with a discrete atomic structure, such as points and lines.

As is shown in Figure 9, a geological model can be generated by using this technique. Students first need to collect related data and information, including geographic coordinate systems, the surface elevation information, etc. The stratum information, contact relationship, etc. are obtained through the site. Finally they can complete a geological model based on which route map, profile map, grid figure, etc. are created.

Over the last few years, information technology has progressed from being an exciting cutting-edge technology with much potential to being the standard method of recording field data and constructing geologic maps. Geoscience professionals in positions within state surveys, geotechnical consulting firms and hydraulic and civil exploration companies have stressed the importance of familiarity with information technology. Similarly, feedback from university field course students that have gone on to graduate programs indicates the value of exposure to information technology. These advantages often extend beyond improved 3D understanding of geologic features to have application to many disciplines.

\section{Attempts toward International Cooperation in Teaching}

The research by academia on the internationalization of higher education dates back to the 1960s. Professor R. Freeman Butts (Butts \& Wirth, 1964; Butts, 1969) defined international education as "embracing the programs of activity which identifiable educational organizations deliberately plan and carry out for their members (students, teachers, and closely related clientele), with one of (or possibly both) two major purposes in mind: a) the study of the thought, institutions, techniques, or ways of life of other people and of their interrelationships; and b) the transfer of educational institutions, ideas, or materials from one society to another" (Knowles, 1977). Wang (Wang, 2001) believed that indirect internationalization mainly included the education of foreign students and international cooperation in running schools, etc. The teaching of foreign students is an important symbol of inter- 

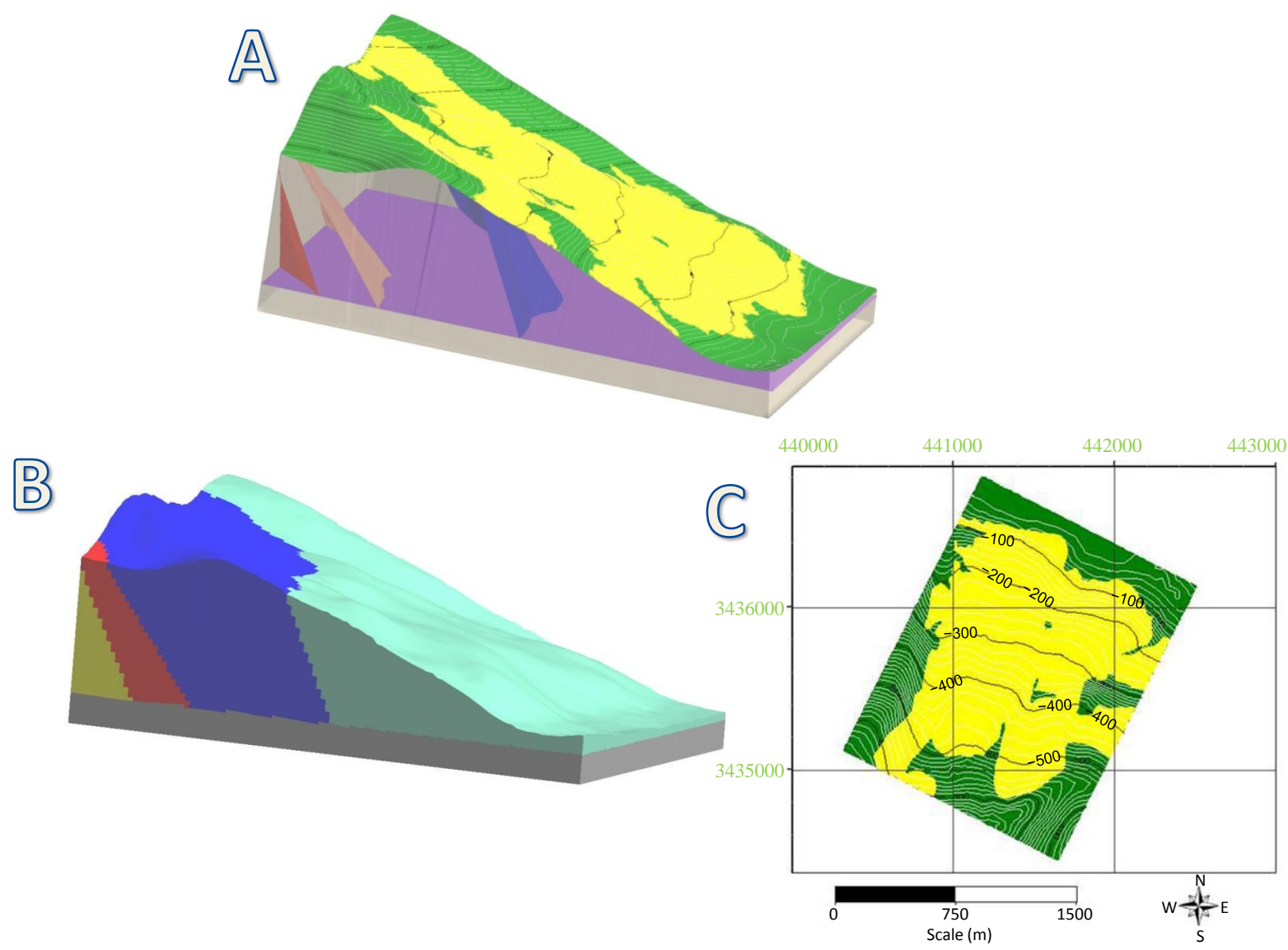

Figure 9. 3D geological model of a landslide along the route from the Lanling Brook to Quyuan Town. (A) 3D model with smooth surfaces; (B) 3D model with grid; (C) map projected from the 3D surface.

national standards for a university. In China, the college training model has some obvious flaws and problems because of the influence of traditional educational thinking. Therefore, the pattern of international talent training in developed countries can undoubtedly provide useful knowledge.

Since 2009, Sinohydro Corporation has invested nearly 4 million US dollars to fund 60 students from Angola to study at Wuhan University. This has played a positive role in promoting the communications and cultural exchanges between China and Angola. At the same time, it also provides the resources for Wuhan University to carry out international teaching research to benefit the geological field course.

The official language of Angola is Portuguese, and the language of instruction for the field course is English. There is no doubt that Chinese teachers' language ability could improve. The instructors need not only a strong reading and writing ability in a foreign language but also listening and speaking abilities. In addition, compared with Chinese students, the mathematical and mechanical foundation of Angolan students is generally poor, and care should be taken to use appropriate methods when guiding them. Coupled with the differences of language and culture, there have been challenges in the field course. Hence, it is absolutely vital to prepare careful plans that address various situations. Facing cross-cultural adaptation problems, the international students have to undergo a psychological adjustment and social cultural learning in the host country. Cross-cultural adaptation can include psychological, sociocultural and academic adaptations. Consequently, teachers must combine the course teaching with language and humanistic care. After a week of field practice (Figure 10), Angolan students mastered the basic knowledge of lithology and geological structure and the analysis methods of the engineering geological conditions in a hydropower project. Meanwhile, the trip also strengthened their communication with Chinese students and understanding of Chinese culture. After the week of field practice, all students are encouraged to attend a daylong field trip. This trip is intended to be enjoyable while still being a learning experience; it is largely show-and-tell and incorporates scenic stops of geologic significance. Through the field practice, it is 

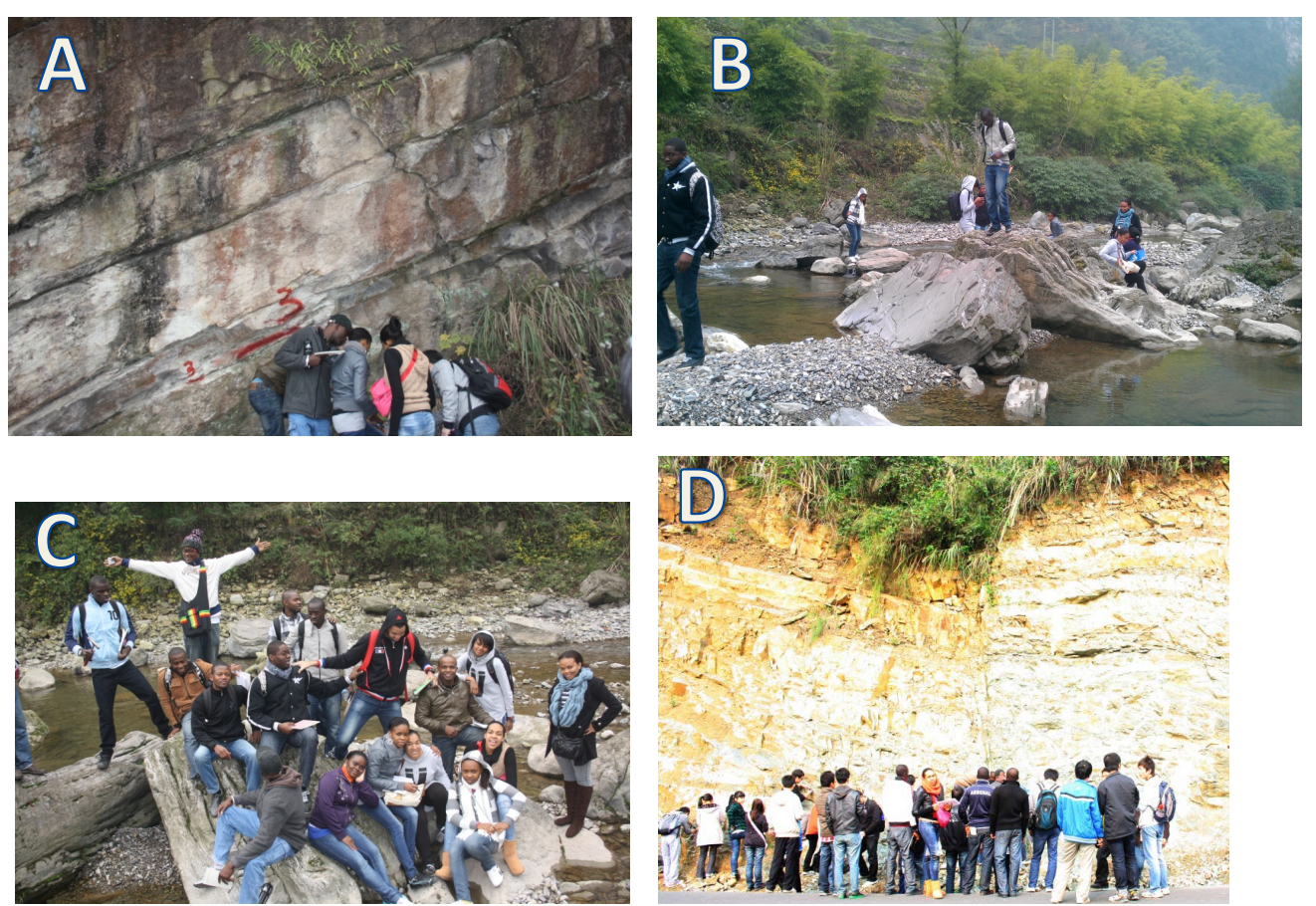

Figure 10. Angolan students in the geological field course 2010. (A) Measurement of the attitude of strata at the Liantuo Group (Sinian Period); (B) fluvial geomorphology survey; (C) the group photo above the Sinian strata; (D) analysis of fault characteristics.

verified that the field course process is effective for international students.

\section{Conclusions}

By carrying out the geological field course in Zigui County of The Three Gorges Reservoir area for four years, the university has accumulated certain experience in teaching. The students' learning outcomes of the field projects were substantial, as indicated by high levels of student devotion and enthusiasm, observed gains in technical and cognitive field skills, and good results on the test after the course.

The interviews conducted with students indicate that the amount of information obtained from the practice has increased and that different methods of exploring a geology problem have been adopted by the students. We have developed a Field Geoscience Concept Inventory (FGCI) to assess students' conceptual knowledge particular to geosciences. The FGCI is a test bank with 30 questions about field geology course (Please contact the authors directly for a complete list of the 30 questions). A 5-item FGCI was selected in the course of interview for every student. The short field course cultivates students' ability to collect and process field geological information and perform a comprehensive analysis. In addition, students have grasped the basic field work method, such as the use of the compass and geologic-topographic map, identification of the lithology and structure, etc. Moreover, they learn the basics of drawing geological maps and writing geological reports. Combining the theory taught in the classroom with the field course enhances the theoretical knowledge learned in classes and strengthens the students' geological thinking abilities.

The Zigui field site has the Three Gorges Project. New content and experiments are added during the teaching. There is a steady increase in the interaction between students and professors, and students take the initiative to learn. The geological field course has been one of the most interesting courses for both Chinese and international students. By placing students beyond the comfort of their home learning environment, the Zigui field course motivates student curiosity, heightens awareness and comprehension, and amplifies the desire to learn. The intensity of living and studying in a different place builds strong group camaraderie and mentoring relationships among students and faculty. The course serves as a capstone experience that synthesizes critical skills taught throughout the curriculum. The understanding and perspective gained by field experience provides essential skills, stimulates creativity, and instills a diligent curiosity and passion for lifelong development in geology. 


\section{Acknowledgements}

This work was supported by the Teaching Reform Project of Wuhan University and Hubei Province under the Contract no. JG2013036/2013027.

\section{References}

American Geological Institute (AGI) (2009). Status of the Geoscience Workforce 2009. http://www.agiweb.org/workforce/reports/2009-AppendixA.pdf

Butts, R. F. (1969). America's Role in International Education: A Perspective on Thirty Years. Chicago: National Society for the Study of Education.

Butts, R. F., \& Wirth, A. G. (1964). American Education in International Development. Journal of Higher Education, 35, 474.

California State University (2014). What Is Geology? https://www.csustan.edu/geology/gamma-phi-kappa

Feltrin, L., Mclellan, J. G., \& Oliver, N. H. S. (2009). Modelling the Giant, zn-pb-ag Century Deposit, Queensland, Australia. Computers \& Geosciences, 35, 108-133. http://dx.doi.org/10.1016/j.cageo.2007.09.002

Geissman, J. W., \& Meyer, G. (2009). Introductory Field Geology at the University of New Mexico, 1984 to Today: What a “Long, Strange Trip” It Continues to Be. Geological Society of America Special Papers, 461, 35-44. http://dx.doi.org/10.1130/2009.2461(04)

Knowles, A. S. E. (1977). The International Encyclopedia of Higher Education (Vol. 5). San Francisco: Jossey-Bass Publishers.

Losier, L. M., Pouliot, J., \& Fortin, M. (2007). 3d Geometrical Modeling of Excavation Units at the Archaeological Site of Tell 'Acharneh (syria). Journal of Archaeological Science, 34, 272-288. http://dx.doi.org/10.1016/j.jas.2006.05.008

Mallet, J. L. (1989). Discrete Smooth Interpolation. ACM Transactions on Graphics, 8, 121-144. http://dx.doi.org/10.1145/62054.62057

Mallet, J. L. (2002). Geomodeling. New York: Oxford University Press.

Marshall, J. S., Gardner, T. W., Protti, M., \& Nourse, J. A. (2009). International Geosciences Field Research with Undergraduate Students: Three Models for Experiential Learning Projects Investigating Active Tectonics of the Nicoya Peninsula, Costa Rica. Geological Society of America Special Papers, 461, 77-98. http://dx.doi.org/10.1130/2009.2461(08)

Paor, D. G. D., \& Whitmeyer, S. J. (2009). Innovation and Obsolescence in Geoscience Field Courses: Past Experiences and Proposals for the Future. Geological Society of America Special Papers, 461, 45-56.

http://dx.doi.org/10.1130/2009.2461(05)

Swanson, M. T., \& Bampton, M. (2009). Integrated Digital Mapping in Geologic Field Research: An Adventure-Based Approach to Teaching New Geospatial Technologies in Anreu-Site Program. Geological Society of America Special Papers, 461, 117-133. http://dx.doi.org/10.1130/2009.2461(11)

University of Wisconsin-Milwaukee (2014). UW-Milwaukee: Geosciences_Field Camp Information. http://uwm.edu/geosciences/undergraduate/resources/field-camp/

Wang, T. et al. (2014). Teaching Reform Research on Engineering Geological Field Practice of Water Resources and Hydropower Specialty. Chinese Geological Education, No. 2, 107-111.

Wang, X. (2001). The Internationalization of Higher Education in the American Human Eyes. Higher Education Exploration, No. 4, 40-43.

Wet, A. D., Manduca, C., Wobus, R. A., \& Bettisonvarga, L. (2009). Twenty-Two Years of Undergraduate Research in the Geosciences-The Keck Experience. Geological Society of America Special Papers, 461, 163-172. http://dx.doi.org/10.1130/2009.2461(14)

Whitmeyer, S. J., Mogk, D. W., \& Pyle, E. J. (2009). An Introduction to Historical Perspectives on and Modern Approaches to Field Geology Education. Geological Society of America Special Papers, 461, vii-ix.

http://dx.doi.org/10.1130/2009.2461(00) 


\section{Submit or recommend next manuscript to SCIRP and we will provide best service for you:}

Accepting pre-submission inquiries through Email, Facebook, Linkedin, Twitter, etc A wide selection of journals (inclusive of 9 subjects, more than 200 journals)

Providing a 24-hour high-quality service

User-friendly online submission system

Fair and swift peer-review system

Efficient typesetting and proofreading procedure

Display of the result of downloads and visits, as well as the number of cited articles

Maximum dissemination of your research work

Submit your manuscript at: http://papersubmission.scirp.org/ 